\title{
PERAN LEMBAGA KEUANGAN MIKRO SYARIAH TERHADAP PEMENUHAN KEBUTUHAN PERMODALAN USAHA MIKRO KECIL DAN MENENGAH
}

\section{THE ROLE OF ISLAMIC MICROFINANCE INSTITUTIONS IN FULLFILLING MICRO SMALL AND MEDIUM ENTERPRISES CAPITAL NEEDS}

\author{
M.Paramita19; M.I.Zulkarnain²; \\ 1aProgram Studi Ekonomi Syariah Fakultas Ekonomi Islam Universitas Djuanda, \\ Jl. Tol Ciawi No. 1, Kotak Pos 35 Bogor 16720, e-mail: metti.paramita@unida.ac.id \\ 2Program Studi Ekonomi Syariah Fakultas Ekonomi Islam Universitas Djuanda, \\ Jl. Tol Ciawi No. 1, Kotak Pos 35 Bogor 16720, e-mail: \\ muhammad.iskandar2097@gmail.com
}

\begin{abstract}
This study aims to determine the role of Islamic microfinance institutions in fulfilling micro small and medium enterprises capital needs. The research method used is qualitative research with data analysis technique using analytical descriptive analysis. Samples taken as many as 20 key respondents who use business capital from sharia financial institutions Kota and Kabupaten Bogor. The results of the study found that the role of islamic microfinance institutions in providing business capital to businesses has an important role to improve small and medium enterprises as well as the state economy.
\end{abstract}

Keywords: Micro small and medium enterprises, Capital, Business needs fulfilling.

\begin{abstract}
Penelitian ini bertujuan untuk mengetahui peran lembaga keuangan mikro syariah terhadap pemenuhan kebutuhan permodalan usaha mikro kecil dan menengah. Metode penelitian yang digunakan adalah penelitian kualitatif dengan teknik analisis data menggunakan analisis deskriptif analitis. Sampel yang diambil sebanyak 20 responden kunci yang menggunakan permodalan usaha dari lembaga keuangan mikro syariah Kota dan Kabupaten Bogor. Hasil penelitian menemukan bahwa peran lembaga keuangan mikro syariah dalam memberikan permodalan usaha kepada usaha memiliki peran penting untuk meningkatkan usaha mikro kecil dan menengah serta perekonomian negara
\end{abstract}

Kata Kunci: Usaha Mikro Kecil dan Menengah, Permodalan, Pemenuhan kebutuhan usaha.

Paramita, Metti. 2018. Peran Lembaga Keuangan Mikro Syariah Terhadap Pemenuhan Kebutuhan Permodalan Usaha Mikro Kecil dan Menengah. Jurnal Syarikah 4 (1): 72-82. 


\section{PENDAHULUAN}

Usaha Mikro Kecil dan Menengah (UMKM) adalah unit usaha produktif yang berdiri sendiri, yang dilakukan oleh orang perorangan atau badan usaha disemua sektor ekonomi (Tambunan, 2012:2). UMKM merupakan usaha yang mampu bertahan di tengah krisis ekonomi yang telah melanda sejak tahun 1997, bahkan menjadi katup penyelamat bagi pemulihan ekonomi bangsa karena kemampuannya memberikan sumbangan yang cukup signifikan pada PDB maupun penyerapan tenaga kerja (Ravik dan Heru, 2005)

Sejak saat itu peranan UMKM dalam menopang perekonomian nasional maupun regional dari tahun ke tahun baik eksistensi, ketangguhan maupun kontribusinya terus meningkat. Keberhasilan UMKM ini dikarenakan, pertama, UMKM tidak memiliki utang luar negeri dan tidak banyak utang ke perbankan. Kedua, sektor-sektor kegiatan UMKM, seperti pertanian, perdagangan, industri rumah tangga, dan lain-lainnya tidak bergantung sumber bahan baku dari luar negeri. UMKM menggunakan bahan baku lokal yang diperoleh dari potensi daerah sekitar perusahaan. Ketiga, walaupun belum semuanya, UMKM berorientasi ekspor, dapat dikatakan UMKM merupakan soko guru perekonomian nasional. Sumbangan UMKM terhadap produk domestik bruto (PDB) mencapai 54\%-57\%, dan kontribusinya terhadap penyerapan tenaga kerja sekitar 96\% (Kementerian Koperasi dan UKM, 2011).

Berbagai upaya untuk menjadikan UMKM sebagai penggerak roda perekonomian masih menghadapi berbagai tantangan terkait dengan keberadaannya yang bersifat income gathering. Usaha yang dijalankan bertujuan untuk menaikkan pendapatan dengan ciri-ciri umum merupakan usaha milik keluarga, menggunakan teknologi yang masih relatif sederhana, dan tidak ada pemisahan modal usaha dengan kebutuhan pribadi. Masalah lain yang kemudian muncul seperti keterbatasan modal kerja, kapasitas sumber daya manusia yang rendah, dan minimnya penguasaan ilmu pengetahuan dan teknologi, yang secara umum berimplikasi terhadap prospek usaha yang kurang jelas.

Salah satu masalah dalam perkembangan UMKM adalah keterbatasan modal yang dimiliki dan sulitnya mengakses sumber permodalan. Mengutip laporan BPS, Dibyo Prabowo (2004 dalam Noer, 2005) menegaskan bahwa $35,10 \%$ UKM menyatakan kesulitan permodalan, kemudian diikuti oleh kepastian pasar 25,9\% dan kesulitan bahan baku 15,4\%. Dalam kondisi yang demikian kelompok ini akan sangat sulit keluar dari permasalahan yang biasanya sudah berjalan lama tersebut, kecuali bila ada intervensi dari pihak lain yaitu lembaga keuangan syariah.

Keterbatasan akses sumber-sumber pembiayaan yang dihadapi oleh pelaku UMKM terutama dari lembaga-lembaga keuangan formal seperti perbankan, menyebabkan mereka bergantung pada sumber-sumber informal. Bentuk dari sumber-sumber ini beraneka ragam mulai dari pelepas uang (rentenir) hingga berkembang dalam bentuk unit-unit simpan pinjam, koperasi dan bentukbentuk lainnya yang lazim disebut sebagai Lembaga Keuangan Mikro (LKM). Kehadiran lembaga keuangan mikro, dalam hal ini mikro syariah, menjadi peluang cemerlang untuk bisa turut andil dalam pengembangan dan pemberdayaan UMKM. Hal ini dikarenakan dalam perkembangannya, kemudahan akses dan persyaratan yang ditawarkan lembaga keuangan mikro syariah lebih mengena di kalangan pelaku UMKM karena sifatnya yang lebih fleksibel, misalnya dalam hal persyaratan dan jumlah pinjaman yang tidak seketat persyaratan perbankan 
maupun keluwesan pada pencairan pembiayaan. Hal ini merupakan salah satu indikator bahwa keberadaan lembaga keuangan mikro syariah sesuai dengan kebutuhan pelaku UMKM, yang umumnya membutuhkan pembiayaan sesuai skala dan sifat usaha kecil.

Permodalan merupakan salah satu sumber daya yang penting bagi perusahaan. Menurut Riyanto (2001:57), permodalan adalah dana untuk membelanjai operasional perusahaan sehari-hari. Permodalan sangat berpengaruh bagi suatu perusahaan, karena tanpa adanya permodalan perusahaan tidak bisa menjalankan kegiatan operasinya.

Menurut Sumarni (2000:315), tersedianya permodalan yang cukup merupakan suatu syarat agar perusahaan dapat memenuhi kebutuhannya dan melaksanakan kegiatan sehari-hari dengan lancar. Permodalan yang berlebihan menunjukkan adanya dana yang tidak produktif dan hal ini memberikan kerugian karena dana yang tersedia tidak dipergunakan secara efektif dalam kegiatan perusahaan. Sebaliknya, kekurangan permodalan merupakan sebab utama kegagalan perusahaan dalam menjalankan aktivitasnya.

\section{MATERI DAN METODE}

UMKM adalah unit usaha produktif yang berdiri sendiri, yang dilakukan oleh orang perorangan atau Badan Usaha disemua sektor ekonomi (Tambunan, 2012:2). Di Indonesia, klasifikasi UMKM diatur berdasarkan Undang-Undang Republik Indonesia Nomor 20 Tahun 2008 tentang Usaha Mikro, Kecil, dan Menengah.
Tabel 1. Klasifikasi UMKM

\begin{tabular}{|l|l|l|}
\hline \multicolumn{1}{|c|}{$\begin{array}{c}\text { Ukuran } \\
\text { Usaha }\end{array}$} & \multicolumn{1}{c|}{ Asset } & \multicolumn{1}{c|}{ Omset } \\
\hline Usaha Mikro & $\begin{array}{l}\text { Maksimal 50 } \\
\text { Juta }\end{array}$ & $\begin{array}{l}\text { Maksimal } \\
\text { 300 Juta }\end{array}$ \\
\hline Usaha Kecil & $\begin{array}{l}>50 \text { Juta }- \\
500 \text { Juta }\end{array}$ & $\begin{array}{l}\text { Maksimal 3 } \\
\text { Miliar }\end{array}$ \\
\hline $\begin{array}{l}\text { Usaha } \\
\text { Menengah }\end{array}$ & $\begin{array}{l}>500 \text { Juta }- \\
10 \text { Miliar }\end{array}$ & $\begin{array}{l}>2,5-50 \\
\text { Miliar }\end{array}$ \\
\hline
\end{tabular}

Sumber : Kementrian Koperasi dan Usaha

Kecil dan Menengah, 2012

Pengembangan usaha mikro dapat memberikan kontribusi pada diversifikasi ekonomi dan perubahan struktur sebagai prakondisi pertumbuhan ekonomi jangka panjang yang stabil dan berkesinambungan. Disamping itu tingkat penciptaan lapangan kerja lebih tinggi pada usaha mikro dibandingkan yang terjadi di perusahaan besar (Sutrisno dan Sri, 2006).

Menurut Dwiwinarno (2008 dalam Haryadi, 2010), ada beberapa faktor penghambat berkembangnya UMKM (Usaha Mikro, Kecil dan Menengah) antara lain kurangnya modal dan kemampuan manajerial yang rendah. Meskipun permintaan atas usaha mereka meningkat karena terkendala dana maka sering tidak bisa untuk memenuhi permintaan. Hal ini disebabkan karena keterbatasan kemampuan untuk mendapatkan informasi tentang tata cara mendapatkan dana dan keterbasan kemampuan dalam membuat usulan untuk mendapatkan dana. Bagi UMKM nampaknya permodalan tetap menjadi salah satu kebutuhan penting guna menjalankan usahanya, baik kebutuhan modal kerja maupun investasi.

Modal usaha menurut Nugraha (2011:9) "modal usaha adalah uang yang dipakai sebagai pokok (induk) untuk berdagang, melepas uang, dan sebagainya; harta benda (uang, barang, dan sebagainya) yang dapat dipergunakan untuk menghasilkan sesuatu yang menambah kekayaan". Terdapat macam-macam bodal yang 
dimiliki UMKM dalam menjalankan usahanya terdiri dari:

a. Modal Sendiri

Menurut Mardiyatmo mengatakan bahwa modal sendiri adalah modal yang diperoleh dari pemilik usaha itu sendiri. Modal sendiri terdiri dari tabungan, sumbangan, hibah, saudara, dan lain sebagainya.

b. Modal Asing (Pinjaman)

Modal asing atau modal pinjaman adalah modal yang biasanya diperoleh dari pihak luar perusahaan seperti dari pinjaman. Keuntungan modal pinjaman adalah jumlahnya yang tidak terbatas, artinya tersedia dalam jumlah banyak.

Dalam menjalankan kegiatan usaha, UMKM tidak hanya membutuhkan dana yang berasal dari modal sendiri tetapi membutuhkan pula modal dari pihak lain karena permasalahan keterbatasan modal. Modal dari pihak lain dapat bersumber dari pinjaman Lembaga Keuangan Mikro Syariah (LKMS) yang memberikan permodalan melalui pembiayaan syariah. Selain itu terdapat kebijakan pemerintah yang dapat membantu pengembangan UMKM dalam pengelolaan permodalan.

Menurut Paramita (2017:4-5) secara konsepsi LKMS adalah suatu lembaga yang didalamnya mencakup dua jenis kegiatan sekaligus yaitu:

1. Kegiatan mengumpulkan dana dari berbagai sumber seperti: zakat, infaq dan shodaqoh serta lainya yang dibagikan/disalurkan kepada yang berhak dalam rangka mengatasi kemiskinan.

2. Kegiatan produktif dalam rangka nilai tambah baru dan mendorong pertumbuhan ekonomi yang bersumber daya manusia.

Penyaluran pembiayaan LKMS kepada pelaku UMKM dapat melalui transaksi jual beli yang terbagi menjadi tiga yaitu:
1. Murabahah

Murabahah adalah akad jual beli pada harga asal dengan tambahan keuntungan yang disepakati oleh pihak-pihak yang mengadakan akad murabahah (Antonio, 2001 : 101). Menurut Kartini (2017 : 55) manfaat pembiayaan jual beli (murabahah) bagi UMKM, yaitu:

- UMKM mengetahui semua biaya dengan semestinya, serta mengetahui harga pokok barang dan keuntungan yang diartikan sebagai presentase harga keseluruhan ditambah biayabiaya.

- UMKM akan mendapatkan barang atau komoditas untuk modal kerja, investasi dan konsumsi.

- UMKM dapat melakukan pembayaran dengan angsuran.

- UMKM mendapatkan amanah untuk membeli barang sendiri.

2. Isthisna

Dalam kontrak ini pembuat barang menerima pesanan dari pembeli, pemuat barang lalu berusaha melalui orang lain untuk membuat atau membeli barang menurut spesifikasi (jenis, macam, ukuran, mutu, dan jumlahnya) yang telah disepakati dan menjualnya kepada pembeli akhir.

3. Salam

Salam adalah transaksi jual beli dimana barang yang diperjual belikan belum ada. Salam berarti pembelian barang yang diserahkan di kemudian hari sementara pembayaran dilakukan di muka. (Karim, 2009 : 99).

Kontek kebutuhan dalam permodalan pada praktik LKMS secara umum dibagi menjadi dua yakni pembiayaan produktif dan pembiayaan konsumtif. Pembiayaan produktif yaitu pembiayaan yang ditujukan untuk memenuhi kebutuhan produksi. Pembiayaan ini dibagi menjadi dua hal yakni: 
1. Pembiayaan modal kerja

a) Pembiayaan likuiditas (Cash Financing)

Pembiayaan ini umumnya digunakan untuk memenuhi kebutuhan yang timbul akibat terjadinya ketidaksesuaian antara uang yang masuk (Cash inflow) dan uang yang keluar (Cash outflow) pada perusahaan nasabah.

b) Pembiayaan Persediaan (Inventory Financing)

Pada LKMS untuk memenuhi kebutuhan pendanaan persediaan mempunyai mekanisme tersendiri yaitu menggunakan prinsip jual beli (murabahah) dalam dua tahap. Tahap pertama bank mengadakan (membeli barang dari supplier secara tunai) barang-barang yang dibutuhkan oleh nasabah. Pada tahap kedua bank menjual kembali kepada nasabah dengan pembayaran tangguh dan dengan mengambil keuntungan yang disepakati bersama antara LKS dan nasabah.

2. Pembiayaan investasi

Pembiayaan investasi diberikan kepada para nasabah untuk keperluan investasi, yaitu keperluan penambahan modal guna mengadakan rehabilitasi, perluasan usaha, ataupun pendirian proyek baru. Ciri-ciri pembiayaan investasi adalah untuk pengadaan barang-barang modal, mempunyai perencanaan alokasi dana yang matang dan terarah, berjangka waktu menengah dan panjang.

Sedangkan pembiayaan konsumtif yaitu pembiayaan yang digunakan untuk memenuhi kebutuhan konsumsi yang akan habis digunakan untuk memenuhi kebutuhan. Kebutuhan konsumsi dapat dibedakan atas kebutuhan primer dan kebutuhan sekunder. LKMS dapat menggunakan pembiayaan komersil untuk pemenuhan kebutuhan barang konsumsi dengan menggunakan skema jual beli yang dilakukan dengan pembayaran angsuran.

\section{Jenis Penelitian}

Penelitian ini menggunakan jenis penelitian kualitatif yaitu terbatas pada usaha mengungkapkan suatu masalah atau keadaan atau peristiwa sebagaimana adanya sehingga bersifat mengungkapkan fakta dan memberikan gambaran secara obyektif tentang keadaan sebenarnya dari objek yang diteliti. Dasar teoritis dalam pendekatan kualitatif adalah pendekatan interaksi simbolik, diasumsikan bahwa objek orang, situasi dan peristiwa tidak memiliki pengertian sendiri, sebaliknya pengertian itu diberikan kepada mereka.

\section{Populasi dan Sampel}

Populasi dalam penelitian ini adalah UMKM Kabupaten Bogor yang memperoleh permodalan dari LKMS Kota Dan Kabupaten. Sampel penelitian ini yaitu 20 UMKM di Kabupaten Bogor dengan menggunakan metode purposive sampling, yaitu cara pengambilan sampel yang sudah dipilih secara tepat, ciri-ciri tertentu sehingga relevan dengan rancangan penelitian.

\section{Jenis dan Sumber Data}

Data yang diperoleh dalam melakukan penelitian bersumber data primer dan sekunder. Menurut $M$ Paramita (2017:5-6) pengertian data primer dan sekunder yaitu:

1. Data primer, yaitu data yang diperoleh dari responden dengan menggunakan observasi dan wawancara mendalam. Wawancara mendalam akan dilaksanakan kepada tokoh kunci/jumlah terbatas dari responden.

2. Data sekunder, yaitu data-data yang diperoleh dengan cara membaca, mempelajari, dan memahami melalui media lain yang bersumber dari literature-literatur yang terkait dengan kajian penelitian ini. Dalam penelitian ini data tersebut berupa informasi mengenai penelitian yang sedang diteliti yang diperoleh dari berbagai literature baik itu buku, jurnal maupun internet. Data primer dan data skunder 
kemudian diolah dan dianalisis untuk mendapatkan kesimpulan.

\section{Teknik Pengumpulan Data}

Data merupakan hal yang dijadikan sebagai informasi fakta yang diperoleh dari subyek penelitian, informan, pelaku, aktivitas, tempat (Adila, 2017:32).

1. Observasi (pengamatan)

Pengamatan yang dilakukan melalui observasi terbatas dengan berupaya mengumpulkan data primer dan data sekunder.

2. Wawancara

Jenis yang diwawancara pada penelitian ini adalah wawancara terbuka dan semi terstrutur.

3. Dokumentasi

Dalam penelitian ini, peneliti mengumpulkan data - data yang berupa diktat, catatan, arsip dan lain sebagainya yang berhubungan dengan sejarah berdirinya UMKM, susunan kepengurusan, program kegiatan UMKM, permodalan dan produk - produk yang dipasarkan.

\section{Teknik Analisis Data}

Teknik analisis data yang digunakan dalam penelitian ini adalah metode kualitatif. Metode kualitatif adalah suatu penelitian yang mempergunakan data deskriptif analitis, yaitu apa yang dinyatakan oleh responden secara tertulis maupun lisan, juga perilakunya yang nyata diteliti dan dipelajari sebagai suatu bagian yang utuh. Data yang diperoleh dari penelitian lapangan dan penelitian kepustakaan dikumpulkan yang kemudian dianalisis secara sistematis.

Data yang diperoleh dari penelitian lapangan dan penelitian kepustakaan dikumpulkan yang kemudian dianalisis secara sistematis. Dalam analisis data peneliti melalui tiga tahap antara lain: Reduksi data yaitu sebagai proses pemilihan pemusatan perhatian pada penyerdahanaan pengabstrakan dan transformasi data kasar yang muncul dari hasil penelitian lapangan, penyajian data yaitu sebagai kesimpulan informasi yang tersusun dan memberikan kemungkinan adanya penarikan kesimpulan.

\section{HASIL DAN PEMBAHASAN}

\section{Gambaran Umum Responden}

Objek dalam penelitian ini adalah UMK Kabupaten bogor yang menerima permodalan dari LKMS Kota dan Kabupaten Bogor. Karakteristik mengenai responden dapat dilihat pada penjelasan di bawah ini:

1. Berdasarkan gender, penerima kredit laki-laki lebih dominan (sejumlah 17 orang) dibandingkan perempuan sehingga keputusan untuk melakukan pinjaman sangat didominasi oleh lakilaki sedangkan untuk pengelolaan pinjaman itu sendiri kemudian diserahkan kepada perempuan. Berdasarkan rentang usia responden, kelompok usia muda dan produktif masih mendominasi, dan hanya sebagian kecil (4 orang) yang berusia lanjut (45 tahun keatas). Ini artinya bahwa UMKM masih menjadi salah satu pilihan pekerjaan yang dilakukan oleh kelompok usia produktif di kelurahan/ pedesaan. Bila dilihat dari tingkat pendidikan UMKM responden, 9 orang berada di tingkat SMA, dan 4 UMKM yang berpendidikan sarjana sehingga pendidikan tersebut dapat membantu dalam hal pengelolaan usaha.

2. Berdasarkan pengalaman UMKM responden berkisar antara 5-10 tahun, ini menandakan bahwa UMKM sudah menjadi pekerjaan yang dijalankan sudah lama. Luas tempat usaha Usaha UMKM beragam, dengan responden terbanyak yaitu pada tempat usaha seluas $21 \mathrm{~m}^{2}$ sampai $40 \mathrm{~m}^{2}$. Dilihat dari jenis usaha yang dilakukan UMKM responden yang paling besar yaitu pada jenis usaha dagang yaitu sejumlah 9 orang karena banyak masyarakat Kabupaten Bogor memanfaatkan pangsa pasar yang ada 
sehingga banyak responden berprofesi sebagai pedagang dipasar.

3. Berdasarkan besarnya jumlah pinjaman yang diterima responden dari LKMS Kabupaten Bogor, 11 responden meminjam Rp3-Rp7 juta, dimana nasabah yang meminjam 2-3 kali sejumlah 9 responden. Menurut responden alasan yang mendasari mereka melakukan pinjaman ke LKMS adalah karena kemudahan prosedur pengajuan.

\section{Penggunaan permodalan untuk kebutuhan UMKM dari LKMS}

Keseluruhan

responden

menggunakan permodalan dari LKMS Kota dan Kabupaten Bogor dalam bentuk pembiayaan produktif dengan berbagai sifat penggunaannya. Terdapat daftar responden dalam menggunakan permodalan produktif dari LKMS Kabupaten Bogor yaitu:

1. Modal Kerja

Berdasarkan hasil penelitian, responden perabotan rumah tangga dan pedagang daging potong menggunakan keseluruhan permodalan untuk modal kerja sedangkan responden lainnya hanya menggunakan sebagian permodalan untuk modal kerja. Beberapa responden seperti responden konveksi pembuatan pakaian, responden pembuatan sepatu kulit, responden ZB roti gepeng, responden pengolahan tempe dan responden bengkel motor putri menggunakan modal kerja dalam likuiditas dan persediaan sebagai dana tambahan modal sendiri untuk membeli bahan baku dan responden perabotan rumah tangga, responden daging potong, dan responden toko pakaian menggunakan permodalan sebagai modal kerja dalam perdagangan digunakan untuk membeli barang dengan tujuan menambah kuantitas barang dagangan agar mampu melayani konsumen lebih banyak, atau menambah vasriasi produknya.

\section{Investasi}

Terdapat beberapa responden yang menggunakan untuk permodalan dalam investasi yaitu responden konveksi pembuatan pakaian, responden pembuatan sepatu kulit, responden ZB roti gepeng, responden pengolahan tempe, dan bengkel motor putri sebagai pengadaan barang-barang modal untuk menjaga keberlangsungan kegiatan produksi. Barang modal yang dimiliki responden dari hasil permodalan diantaranya mesin, tempat usaha dan produk lain yang sifatnya tahan lama.

\section{Konsumsi}

Keseluruhan responden dalam menjalankan kegiatan usaha hanya menggunakan permodalan LKMS dalam bentuk pembiayaan produktif baik sebagai modal kerja ataupun investasi. Permasalahan yang terjadi dalam hal ini terdapat sebagian kecil responden yaitu responden pedagang sembako dan responden pedagag ayam bakar menggunakan dana pembiayaan produktif sebagai kegiatan konsumsi pribadi. Hal itu terjadi karena kurangnya pendapatan dan rendahnya kemampuan dalam pengelolaan dana sehingga tidak dapat memisahkan antara dana pribadi dan dana untuk usaha.

Terdapat daftar responden dalam menggunakan permodalan produktif dari LKMS Kota Bogor yaitu:

1. Modal Kerja

Berdasarkan penelitian, terdapat 4 responden yang menggunakan keseluruhan permodalan untuk modal kerja yaitu responden fhotocopy, responden pedagang buah, responden pedagang gorengan dan soto, serta responden pedagang leupeut. Sedangkan responden konveksi pembuatan pakaian dan responden pembuatan sandal kulit hanya menggunakan sebagian permodalan untuk modal kerja. Beberapa responden seperti responden pedagang gorengan dan soto, responden konveksi pembuatan pakaian dan responden 
pembuatan sandal kulit menggunakan modal kerja dalam likuiditas dan persediaan sebagai dana tambahan modal sendiri untuk membeli bahan baku dan responden fhotocopy, responden pedagang buah dan responden pedagang leupeut menggunakan permodalan sebagai modal kerja dalam perdagangan digunakan untuk membeli barang dengan tujuan menambah kuantitas barang dagangan agar mampu melayani konsumen lebih banyak, atau menambah vasriasi produknya.

2. Investasi

Terdapat beberapa responden yang menggunakan untuk permodalan dalam investasi yaitu responden fhotocopy, responden pemilik percetakan, responden konveksi pembuatan pakaian, responden pembuatan sandal kulit dan responden pemilik kos-kosan sebagai pengadaan barang-barang modal untuk menjaga keberlangsungan kegiatan produksi. Barang modal yang dimiliki responden dari hasil permodalan diantaranya mesin, tempat usaha dan produk lain yang sifatnya tahan lama.

3. Konsumsi

Keseluruhan responden dalam menjalankan kegiatan usaha hanya menggunakan permodalan LKMS dalam bentuk pembiayaan produktif baik sebagai modal kerja ataupun investasi. Permasalahan yang terjadi dalam hal ini terdapat satu responden yaitu responden pedagang sembako menggunakan dana pembiayaan produktif sebagai kegiatan konsumsi pribadi. Hal itu terjadi karena kurangnya pendapatan dan rendahnya kemampuan dalam pengelolaan dana sehingga tidak dapat memisahkan antara dana pribadi dan dana untuk usaha.

Berdasarkan beberapa kebutuhan UMKM dalam permodalan seperti kebutuhan modal kerja, investasi dan konsumsi, maka pembiayaan yang tepat adalah dengan pembiayaan murabahah. Pembiayaan murabahah adalah pembiayaan yang tepat untuk UMKM karena terdapat beberapa manfaat, yaitu: 1. UMKM mengetahui kejelasan harga barang yang sebenarnya

Pembiayaan murabahah dapat membantu UMKM untuk mengetahui harga yang sebenarnya dari barang yang akan dibeli dari penjual baik harga asal atau harga pokok. Harga yang jelas dalam pembiayaan murabahah dapat digunakan UMKM sebagai acuan untuk membeli barang yang sesuai dengan daya beli UMKM. Pembiayaan murabahah merupakan pembiayaan dengan akad yang bisa dipastikan keuntungannya, sehingga dapat membantu berjalannya usaha UMKM dengan tingkat risiko yang kecil.

2. UMKM dapat memenuhi kebutuhan modal kerja, investasi dan konsumsi

Berdasarkan kebutuhan dari setiap responden, maka pembiayaan murabahah merupakan pembiayaan yang tepat sebagai permodalan untuk menjalankan usaha. Pembiayaan murabahah dapat membantu UMKM dalam usaha yang bersifat produktif seperti modal kerja dan investasi maupun konsumtif untuk kepentingan pribadi. Kebutuhan modal kerja digunakan pelaku UMKM untuk penggunaan persediaan bahan baku dan pembelian mesin.

3. UMKM dapat melakukan pembayaran dengan angsuran

Pembiayaan murabahah dengan sistem pembayaran angsuran akan membantu UMKM dalam masalah keuangannya karena pendapatan usahanya yang tidak bisa diperkirakan. Selain itu UMKM dapat membayar angsuran dengan waktu yang di inginkan baik per minggu atau per bulan yang harus disesuaikan dengan kapasitas atau kemampuan UMKM.

4. UMKM mendapatkan kuasa untuk membeli barang sendiri.

UMKM dapat menggunakan pembiayaan murabahah dengan aplikasi akad wakalah seperti skema dibawah ini: 


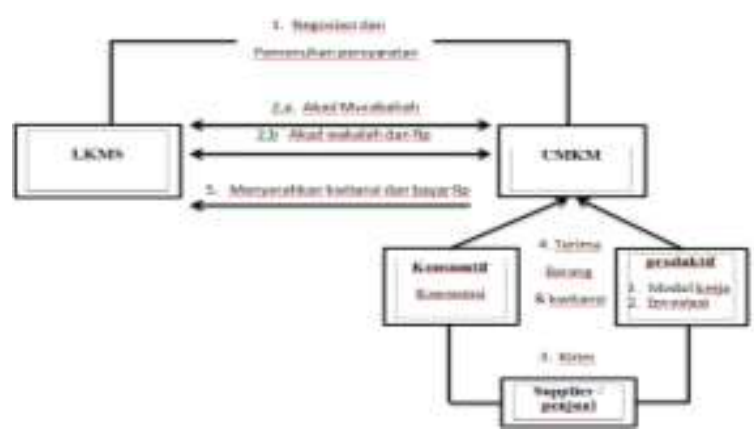

Gambar 1 Skema Pembiayaan Murabahah dengan Teknis Wakalah

Pembiayaan murabahah dengan teknis perwakilan dapat membantu UMKM untuk melakukan transaksi langsung dengan penjual sehingga UMKM mendapatkan barang yang sesuai dengan kebutuhannya.

\section{Peningkatan Aset Setelah Menerima Permodalan dari LKMS}

Berikut ini, peningkatan aset pelaku UMKM sebelum dan setelah memperoleh permodalan dari LKMS Kota dan Kabupaten Bogor.

\section{Tabel 2. peningkatan aset responden (sebelum dan sesudah menerima permodalan di LKMS Kabupaten Bogor)}

\begin{tabular}{|c|c|c|c|}
\hline $\begin{array}{l}\mathbf{N} \\
\mathbf{0}\end{array}$ & $\begin{array}{l}\text { Aset } \\
\text { Sebelum }\end{array}$ & Aset Sesudah & Keterangan \\
\hline 1 & 1 Mesin jahit & $\begin{array}{l}2 \text { Mesin jahit dan } \\
\text { benang }\end{array}$ & Meningkat \\
\hline 2 & 1 Mesin jahit & $\begin{array}{l}2 \text { mesin jahit dan } \\
\text { bahan kulit }\end{array}$ & Meningkat \\
\hline 3 & Perabotan & $\begin{array}{l}\text { Penambahan } \\
\text { kuantitas } \\
\text { perabotan }\end{array}$ & Meningkat \\
\hline 4 & $\begin{array}{l}\text { Daging } \\
\text { potong }\end{array}$ & $\begin{array}{l}\text { Penambahan } \\
\text { kuantitas daging } \\
\text { potong }\end{array}$ & Meningkat \\
\hline 5 & Sembako & Sembako & Tetap \\
\hline 6 & Ayam bakar & Ayam bakar & Tetap \\
\hline 7 & Pakaian & $\begin{array}{l}\text { Penambahan } \\
\text { Kuantitas pakaian }\end{array}$ & Meningkat \\
\hline 8 & $\begin{array}{l}2 \underset{\text { mesin }}{\text { produksi }}\end{array}$ & $\begin{array}{l}3 \text { mesin produksi } \\
\text { dan bahan baku }\end{array}$ & Meningkat \\
\hline 9 & $\begin{array}{l}1 \text { mesin } \\
\text { penggiling }\end{array}$ & $\begin{array}{l}2 \text { mesin penggiling } \\
\text { dan bahan baku } \\
\text { kedelai }\end{array}$ & Meningkat \\
\hline $\begin{array}{l}1 \\
0\end{array}$ & $\begin{array}{l}1 \text { mesin } \\
\text { pompa ban }\end{array}$ & $\begin{array}{l}2 \text { mesin dan } \\
\text { aksesoris motor }\end{array}$ & Meningkat \\
\hline
\end{tabular}

Sumber: Hasil Penelitian

Berdasarkan hasil penelitian, sebagian besar responden yang menggunakan permodalan LKMS Kabupaten Bogor mengalami peningkatan aset diantaranya responden $1,2,3,4,7,8$,
9 dan 10. Hal tersebut terjadi karena responden menggunakan permodalan untuk kegiatan usaha dengan kegunaan sebagai modal kerja dan investasi. Sebagian kecil responden yaitu 5 dan 6 tidak mengalami peningkatan aset dikarenakan menggunakan permodalan sebagai kebutuhan pribadi seperti biaya pembelian bahan makanan dan pembelian barang-barang rumah tangga.

\section{Tabel 3. peningkatan aset responden}

(sebelum dan sesudah menerima permodalan di LKMS Kota Bogor)

\begin{tabular}{|c|c|c|c|}
\hline No & Aset Sebelum & Aset Sesudah & Keterangan \\
\hline 1 & Peralatan ATK & $\begin{array}{l}\text { Penambahan } \\
\text { kuantitas ATK }\end{array}$ & Meningkat \\
\hline 2 & $\begin{array}{l}1 \text { Mesin Fhoto } \\
\text { Copy }\end{array}$ & $\begin{array}{l}1 \text { mesin Fhoto Copy } \\
\text { dan } 1 \text { mesin printer }\end{array}$ & Meningkat \\
\hline 3 & Buah & $\begin{array}{l}\text { Penambahan } \\
\text { kuantitas dan jenis } \\
\text { buah }\end{array}$ & Meningkat \\
\hline 4 & $\begin{array}{l}\text { Bahan gorengan } \\
\text { dan soto }\end{array}$ & $\begin{array}{l}\text { Penambahan } \\
\text { kuantitas bahan dan } \\
\text { menu soto }\end{array}$ & Meningkat \\
\hline 5 & Leupeut & $\begin{array}{ll}\text { penambahan } & \\
\text { kuantitas } & \text { bahan } \\
\text { leupeut dan menu } \\
\text { gorengan }\end{array}$ & Meningkat \\
\hline 6 & Sembako & Sembako & Tetap \\
\hline 7 & $\begin{array}{l}\text { Alat sablon dan } \\
\text { percetakan }\end{array}$ & $\begin{array}{l}\text { Bertambah kabel dan } \\
\text { cat }\end{array}$ & Meningkat \\
\hline 8 & 1 Mesin jahit & $\begin{array}{l}2 \text { Mesin jahit dan } \\
\text { benang }\end{array}$ & Meningkat \\
\hline 9 & 1 Mesin jahit & $\begin{array}{l}2 \text { mesin jahit dan } \\
\text { bahan kulit }\end{array}$ & Meningkat \\
\hline 10 & 5 kamar kos & 6 kamar kos & Meningkat \\
\hline
\end{tabular}

Sumber: Hasil Penelitian

Berdasarkan tabel di atas, sebagian besar responden yang menggunakan permodalan LKMS Kabupaten Bogor mengalami peningkatan aset diantaranya responden 1, 2, 3, 4, 5, 7, 8, 9 dan 10 . Hal tersebut terjadi karena responden menggunakan permodalan untuk kegiatan usaha dengan kegunaan sebagai modal kerja dan investasi. Terdapat satu responden yaitu 6 tidak mengalami peningkatan aset dikarenakan menggunakan permodalan sebagai kebutuhan pribadi seperti biaya pembelian bahan makanan dan pembelian barang-barang rumah tangga. 


\section{KESIMPULAN DAN IMPLIKASI}

Lembaga Keuangan Mikro Syariah telah menunjukan perannya dalam pemenuhan kebutuhan usaha UMKM melalui produk pembiayaan atau permodalan yang dapat menambah peningkatan aset. Peningkatan aset UMKM dapat terjadi karena pengelolaan permodalan oleh UMKM sebagai kegiatan produktif seperti modal kerja dan investasi, namun penggunaan modal sebagai konsumsi tidak berpengaruh terhadap peningkatan aset. Selain itu terdapat Kebijakan Pemerintah dalam pengembangan UMKM diantaranya pemberian akses permodalan, pembinaan atau pelatihan, peningkatan promosi produk, perluasan pemasaran dan penyediaan sarana dan prasarana. Hal tersebut tidak terjadi pada semua responden yang mendapatkan kebijakan pemerintah.

\section{DAFTAR PUSTAKA}

Adi Rinekso, Gidion. P. 2011. "Akses Usaha Mikro Kecil dan Menengah ke Perbankan di Kabupaten Gunung Kidul dan Sleman." JRMB: 1-8.

Ahmad, Kamarudin. 1997. Dasar-dasar Manajemen Modal Kerja. Jakarta: PT Rineka Cipta

Akbar, Fikih. 2008. Sistem Pendukung Keputusan (Decision Support System). dikutip dari http://fakbar.blogspot.com/2008/0 9/

Alyas, Muhammad Rakib. 2017. "Strategi Pengembangan Usaha Mikro, Kecil dan Menengah Dalam Penguatan Ekonomi Kerakyatan (Studi Kasus Pada Usaha Roti Maros di Kabupaten Maros)."

Sosiohumaniora: 114-120.

Dinas Koperasi dan UMKM Provinsi Jawa Tengah. 2015. Time Series Data
UMKM Binaan Provinsi Jawa Tengah Triwulan IV 2014.

Fitriana, Widya. 2016. "Lembaga Keuangan Mikro Syariah: Eksistensi dan Aksesibilitasnya Bagi Pembiayaan Usahatani di Sumatera Barat (Studi Kasus: Koperasi Jasa Keuangan Syariah (KJKS) Baitul Maal Wat Tamwil (BMT))." Agribisnis Indonesia: 149-162.

Hafni, Roswita, dan Ahmad Rozali. 2016. "Analisia Usaha Mikro, Kecil dan Menengah (UMKM) Terhadap Penyerapan Tenaga Kerja Di Indonesia." E-Jurnal, t.thn.: 77-96.

Karsidi, R \& Irianto, H. 2005. Strategi Pemberdayaan UMKM di Wilayah Surakarta. Dalam Diskusi Regional Kerjasama Bank Indonesia Solo dengan Badan Koordinasi Pembangunan Lintas Kabupaten/Kota Wilayah II Surakarta Propinsi Jawa Tengah. Hotel Sahid Raya Solo, 30 Juni 2005.

Kim. 2001. The Greening Strategy of Small and Medium Enterprises (SMEs).

Kuncoro, Amin, dan Husnurrosyidah. 2017. "Kinerja Lembaga Keuangan Mikro Syariah dan Upaya Untuk Mempertahankan Eksistensi Perilaku Masyarakat Pedesaan." Analisa Akuntansi dan Perpajakan: 63-74.

Kusmiyati, Asmi Nur Siwi. 2007. "Risiko Akad dalam Pembiayaan Murabahah Pada BMT di Yogyakarta (Dari Teori ke Terapan)." La_Riba: 27-41.

M. Umer Chapra dan Habib Ahmed. 2008. Corporate Governance Lembaga Keuangan Syariah, diterj. Oleh Ikhwan Abidin Basri, (Jakarta: Bumi Aksara)

Magribi, La Ode Muhamad, dan Suhardjo. Aj. 2004. "Aksesibilitas dan Pengaruhnya Terhadap Pembangunan di Pedesaan : Konsep Model Sustainable Accessibility pada Kawasan Pedesaan di Provinsi 
Sulawesi Tenggara." Transportasi: 149-160.

Mariani, Ita. SE.,M.Si. 2017. "Pengaruh Perkembangan Usaha Mikro Kecil dan Menengah (UMKM) Terhadap Kepuasan Nasabah Koperasi Simpan Pinjam Surya Abadi Mandiri (KSP SAM) Medan Krio." Ilmiah Research Sains: 1-4.

Mcleod, Raymon. 2007. Sistem Informasi Manajemen. Edisi kesembilan Terjemahan Hery Yulianto. Jakarta: PT. Macanan Jaya Cemerlang

Munawir, S. 1998. Analisa Laporan Keuangan. Edisi keempat, cetakan kedelapan. Yogyakarta: Liberty Yogyakarta

Panji Anoraga dan Djoko Sudantoko. 2002. Koperasi Kewirausahaan dan Usaha (Jakarta; Rineka Cipta), cet.ke-1.

Paramita, Metti. 2017. Analisis Sistem Pengembangan Sumber Daya Manusia di Lembaga Keuangan Mikro Syariah. Jurnal Syarikah 3 (2): 343 - 357

Permata, Russely Inti Dwi, Fransisca Yaningwati, dan Zahroh Z.A. 2014 .Analisis Pengaruh Pembiayaan Mudharabah Dan Musyarakah Terhadap Tingkat Profitabilitas (Return on Equity) (Studi Pada Bank Umum Syariah Yang Terdaftar di Bank Indonesia Periode 20092012)." Administrasi Bisnis: 1-9.

Prasetya, Agung. 2016. Peranan Baitul Maal Wa Tamwil Meningkatkan Usaha Mikro Melalui Pembiayaan Mudharabah. Jurnal Syarikah 2 (2). Hal. 252 - 267

Pratiwi, Rianti. "Peranan Lembaga Keuangan Mikro Syariah Dalam
Mendorong Usaha Kaum Perempuan." Ekonomi dan Perbankan Syariah, t.thn.: 84-99.

Rahayu, Lestari. 2015. "Aksesibilitas Petani Bawang Merah Terhadap Terhadap Lembaga Keuangan Mikro Syariah Sebagai Sumber Pembiayaan." E-Jurnal: 52-59.

Rahayu, Ninik Sri. 2015. "Kontribusi Lembaga Keuangan Mikro Syariah Terhadap Pemberdayaan Perempuan (Studi Kasus BMT di Kabupaten Sleman Yogyakarta)." Inovasi dan Kewirausahaan: 162180.

Republik Korea: Graduate School of Management, KAIST. Dikutip dari www.googletranslate.republikkorea .com

Ridwan, Muhammad. 2005. Manajemen Baitul Maal Wa Tamwil (BMT), cetakan kedua. Yogyakarta: UII Press

Rodoni, Ahmad dan Abdul Hamid. 2008. Lembaga keuangan syariah. Jakarta: Zikrul Hakim

Suci, Yuli Rahmini. 2017. "Perkembangan UMKM (Usaha Mikro Kecil da

Sudaryanto, Ragimun, dan Rahma Rina Wijayanti. "Strategi Pemberdayaan

Supardi. 2005. Metodologi penelitian ekonomi dan bisnis. Yogyakarta: UII Press.

Menengah) di Indonesia." Imilah Cano Ekonomos: 51-58.

Supriyanto. 2006. "Pemberdayaan Usaha Mikro, Kecil, dan Menengah (UMKM) Sebagai Salah Satu Upaya Penanggulangan Kemiskinan." Ekonomi \& Pendidikan: 1-16. 